\title{
Boon or Bane: Effect of Adjacent YIMBY or NIMBY Facilities on the Benefit Evaluation of Open Spaces or Cropland
}

\author{
Wun-Jheng $W u^{1}\left(\mathbb{D}\right.$, Pei-Ing $W u^{1, *}$ and Je-Liang Liou ${ }^{2} \mathbb{D}$ \\ 1 Department of Agricultural Economics, National Taiwan University, Taipei 10617, Taiwan; \\ vimalawu@gmail.com \\ 2 The Center for Green Economy, Chung-Hua Institution for Economic Research, Taipei 10617, Taiwan; \\ jlliou@cier.edu.tw \\ * Correspondence: piwu@ntu.edu.tw; Tel.: +886-2-3366-2663
}

Citation: Wu, W.-J.; Wu, P.-I.; Liou, J.-L. Boon or Bane: Effect of Adjacent YIMBY or NIMBY Facilities on the Benefit Evaluation of Open Spaces or Cropland. Sustainability 2021, 13, 3998 https://doi.org/10.3390/su13073998

Academic Editor: Jacques Teller

Received: 6 March 2021

Accepted: 31 March 2021

Published: 3 April 2021

Publisher's Note: MDPI stays neutral with regard to jurisdictional claims in published maps and institutional affiliations.

Copyright: (c) 2021 by the authors. Licensee MDPI, Basel, Switzerland. This article is an open access article distributed under the terms and conditions of the Creative Commons Attribution (CC BY) license (https:/ / creativecommons.org/licenses/by/ $4.0 /)$.

\begin{abstract}
This is the first study to comprehensively evaluate the benefit of urban open spaces and cropland with different adjacent public facilities seen as locally undesirable ("not in my backyard", NIMBY) or desirable ("yes in my backyard", YIMBY). The total benefit increases or decreases for urban open space and cropland with adjacent NIMBY or YIMBY facilities in a municipality in Taiwan. The results show that for the city as a whole, the current arrangement of NIMBY and YIMBY in different zones decreases the total benefit of urban open spaces in highly urbanized zones and increases the total damage to cropland in extremely rural zones. This indicates a need to avoid further installing NIMBY or YIMBY facilities in already occupied urban open spaces. The results also demonstrate that locating NIMBY or YIMBY facilities near cropland fails to highlight the benefit of YIMBY facilities and magnifies opposition to NIMBY facilities. For individual housing units, the total damage is $1.87 \%$ of the average housing price for cropland-type open space with adjacent NIMBY or YIMBY facilities, and the total benefit is $7.43 \%$ of the average housing price for urban-type open space in a highly urbanized area. In contrast, the total benefit for open space with adjacent NIMBY or YIMBY facilities is a $2.95-13.80 \%$ increase in the average housing price for areas with mixed urban open space and cropland.
\end{abstract}

Keywords: spatial Durbin model; local polynomial regression; YIMBY facilities; NIMBY facilities; willingness to pay; total benefit

\section{Introduction}

The openness and public nature of urban open space and cropland offer the functions of agricultural production, ecological conservation, landscape aesthetics, and outdoor recreation and have gained considerable importance due to their ability to act as a carbon sink and their educational value [1]. This has made urban open space and cropland consistent with one of the Sustainable Development Goals (SDGs) of the United Nations, to "provide universal access to safe, inclusive and accessible, green and public spaces" [2]. Most functions of urban open space and cropland have positive benefits, but there is no monetary market to reveal these benefits. Their importance is inevitably underestimated in region planning of urban open space and/or cropland [3].

In general, if housing is surrounded by open space with diverse vegetation, good facility maintenance, and a large area, there is a positive impact on its price [4]. In contrast, lower quality, or quantity of open space with poor public security or mosquito-breeding areas due to poor maintenance will negatively affect housing prices [5,6]. Previous studies evaluating the benefits of open space have either ignored cropland or have not treated these types of spaces separately, resulting in insufficient planning information. A study found that peripheral urban open space has greater benefits than developed private cropland [7]. This finding suggests that the benefits of urban open space and cropland need to be evaluated differently [8]. Under global liberalization and rapid industrial development, the 
impacts of these types of spaces on the agricultural sector are critical. Society attaches great importance to the multifunctionality of cropland because it serves production functions as well as providing openness [9].

Moreover, previous studies have used the distance between housing and urban open space to evaluate the benefits of the latter $[10,11]$. Few studies consider public facilities embedded in or adjacent to urban open space or cropland [10]. It is clear that some facilities positively affect surrounding housing, with a "yes-in-my-backyard" (YIMBY) effect, while others have negative impacts, with a "not-in-my-backyard" (NIMBY) effect; other facilities might have both YIMBY and NIMBY effects on housing prices [12,13]. For instance, it was found that libraries were the most popular YIMBY facility [14]. In contrast, proximity to facilities such as waste landfills has a higher risk and depresses housing prices. It was specifically found that if the distance between a housing unit and a waste landfill site increases from 0.5 miles to 3.25 miles, the housing price will increase $17-20 \%$ [15]. This finding provides guidelines for the amount of compensation that should be provided to those living near landfill sites.

Nevertheless, it was found that housing closer to a nuclear power plant is pricier in California because many plant employees live nearby, indicating that a NIMBY facility might have a positive effect on surrounding housing prices [16]. Without accounting for the NIMBY and/or YIMBY effects, housing prices may be over- or underestimated. The impact on housing prices from urban open space or cropland depends on the interaction of YIMBY or NIMBY facilities and urban open space or cropland [13,17-19]. Such adjacent effects complicate the benefit evaluation of urban open space and cropland. This information is not only essential for the landscape planning, land use, or allocation of NIMBY or YIMBY facilities in certain regions but is also important in assessing their effect on housing prices [13].

Although a previous study indicated that appropriate evaluation is necessary when open space is adjacent to different facilities, no empirical evidence indicates the possible harm or benefit [13]. Another study takes one step further to examine housing prices under the interaction of open spaces and facilities [19]. However, that study neither takes into account the impacts of open space with adjacent NIMBY or YIMBY facilities located at different distances from housing nor considers the total area of such open space within a specific radius of a housing unit. It is imperative that all such dimensions be considered when evaluating the benefits or harms of open space and cropland. The idea of accounting for the facilities with different characteristics is not just applied to housings in ordinary status. Space rearrangement is certainly required for the prominent change in the new political, economic, social, and cultural state and in its major spatial shifts occurred in the urban restructuring processes $[20,21]$ framing a foundation for the study here to focus on the evaluation of the specific concerned targets in one of the municipalities in Taiwan.

Taiwan's comprehensive National Spatial Land Planning Act (NSLPA) of 2016 distinguishes national land into urban and non-urban land [22]. One major type of non-urban land is cropland. Enforcement of this act ensures food security, balances the development of rural and urban areas, and resists climate change. Furthermore, the development of cropland is irreversible [23]. This act suggests that urban open space and cropland should be viewed as equally important in evaluating benefits or harms for national land planning. Under the NSLPA in Kaohsiung City, the municipality with the greatest land area in Taiwan, the city proposed six development zones. Among these, approximately $90 \%$ of the population is centralized in the business metropolitan living development zone, causing enormous population pressure for the zone. This situation highlights the importance of urban open space in this specific zone and in the city. Cropland covers $16 \%$ of the city, but it has not received equivalent attention. The promotion or arrangement of multiuse public facilities on urban open space or cropland can help determine the increase or decrease in benefits for these spaces with adjacent facilities.

This study is the first to comprehensively evaluate the benefit of urban open space and cropland with different adjacent public NIMBY or YIMBY facilities. A comparison is 
made to identify the total increase or decrease in benefits for urban open space or cropland with different combinations of NIMBY or YIMBY facilities. The benefit in terms of the increase or decrease in average housing price is concurrently assessed. For these purposes, this study employs a spatial Durban hedonic price model (SDM) to evaluate the related benefits for urban open space and cropland with adjacent NIMBY or YIMBY facilities. This model accounts for the spatial dependence arising from both housing prices and attributes affecting housing prices [24,25]. Local polynomial regression is employed to determine the scope of impact of a facility and any spatially related attribute [26,27]. In summary, the important aspects of this study are threefold. First, it uses a very advanced spatial methodology. Second, it comprehensively analyzes the outcomes of benefit evaluation for urban open space and cropland with adjacent YIMBY and NIMBY facilities when these facilities are normally ignored. Third, the analyzed results are suitable for use in allocating the abovementioned facilities within a city. This research sheds light on the planning and design of a specific city and brings together the multiple disciplines of sociology, economics, and management.

The remaining sections of this paper are arranged as follows. Section 2 explains the necessity of evaluating the benefit for urban open space and cropland with adjacent NIMBY or YIMBY facilities. Section 3 presents the study area and evaluation model. Section 4 explains the data sources and variable selection. Section 5 presents the results and discusses the evaluation results and implications. The final section concludes this study.

\section{The Necessity of Evaluating the Benefits of Open Space or Cropland with Adjacent NIMBY or YIMBY Facilities}

There is no consensus on the definition of open space [28]. It seems reasonable to define it as a space that is open and accessible; however, the specific types vary by the definitions of particular countries. The most popular types are parks, green lands, rivers, forests, greenbelts, wetlands, public squares, beaches, protected zones, and cropland [26]. The urban growth boundary (UGB) forms under urbanization when urban sprawl invades rural areas. To a certain degree, cropland functions to cut off urban expansion. Although both urban open space and cropland have living functions, cropland typically has other functions, such as ecology and production. Among these, food security is ensured by the production function of cropland [29]. Its multifunctional value has further made cropland a crucial cushion space for land planning arrangement [30-32].

This study calls both urban open space and cropland "open space". Urban open space and cropland are used separately when necessary. Previous studies of the benefit evaluation of open space have treated open space alone without taking into account all types of adjacent NIMBY or YIMBY facilities of open space. Open space and its adjacent facilities are a new type of open space [13]. Thus, open space with adjacent facilities might have higher or lower benefits than that without depending on the types of facilities and/or people's preference for the facilities. The existence of NIMBY or YIMBY facilities normally arises from the needs of society. These facilities can be used to segregate all types of pollutants, as a buffer to reduce risks of different types of damage, or as a space for greening [17]. Examples include buffer zones along highways, protection areas beside nuclear waste landfills, cemetery greening, large outdoor squares, and parks. This type of use makes a facility a substitute for or complement to an open space. In many circumstances, it is difficult to know the order of arrival of an open space and a facility. As such, open space with adjacent NIMBY or YIMBY facilities is treated as a new object $[13,33,34]$.

Various benefit evaluations regarding open space, including parks, greenbelts, wetlands, forest conservation areas, and cropland, through housing transactions, have been reviewed by [28]. They evaluated the targeted open space shown as (A) in Figure 1. The benefit of open space is evaluated as if it has no adjacent NIMBY or YIMBY facilities or these facilities are neglected either intentionally or unconsciously. The benefit of open space should be evaluated together with the compounded NIMBY or YIMBY facilities to reflect the interaction of open space and facilities when housing is located near NIMBY or 
YIMBY facilities or within the NIMBY or YIMBY impact radius, such as that shown in (B) of Figure 1 [13].

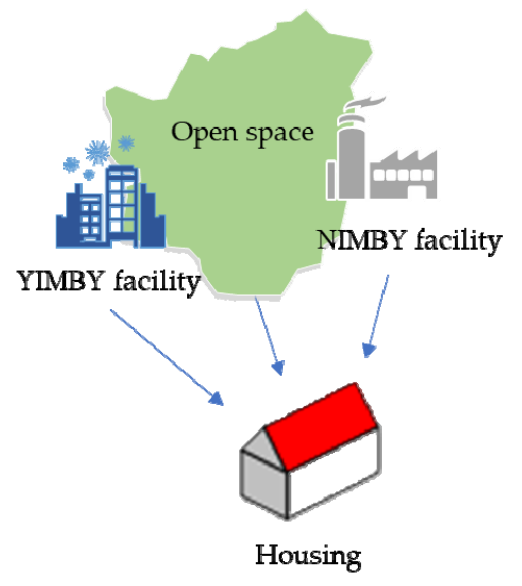

(A)

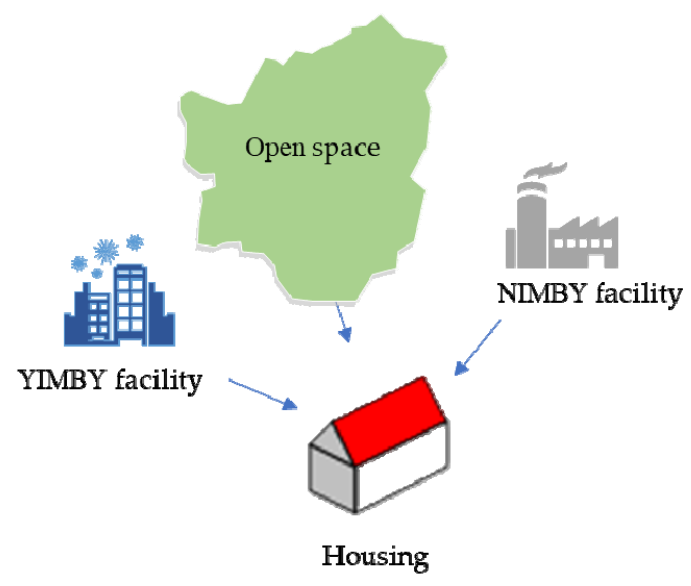

(B)

Figure 1. (A) Impact of urban open space or cropland with adjacent YIMBY or NIMBY facilities on a housing unit. (B) Impact of urban open space or cropland without adjacent YIMBY or NIMBY facilities on a housing unit

How does the benefit of open space change when such space has NIMBY or YIMBY facilities? The answer depends on the implementation of related policies or actions. If there is a compensation scheme or tax cut for those living close to the NIMBY facility, such as a cemetery or any type of waste landfill site, this not only increases the acceptance of residents living nearby but also has high potential to increase the benefit of the original open space $[15,18]$. Similarly, the benefit of urban open space may not be reinforced as expected with adjacent YIMBY facilities, or damage may result from urban open space with adjacent YIMBY facilities due to noise, air pollution, and other disturbances during the construction of a YIMBY facility. To balance the development of rural and urban areas, locating YIMBY facilities such as public libraries or local culture galleries close to cropland may be possible. Specific evaluation is required to determine the extent of the change in benefit for a united open space and NIMBY or YIMBY facility.

\section{Results Study Area and Evaluation Model}

\subsection{Study Area}

Kaohsiung City is in southern Taiwan and has been the second-largest municipality since 1979. There are 38 districts under its administration. The total land acreage of the city is 2948 square kilometers, making it the largest municipality in Taiwan in terms of size. Of this area, urban open space accounts for 36.51 square kilometers, mainly in the business metropolitan development zone and the industrial new county innovation development zone under the NSLPA. The total area of these zones accounts for only $1.24 \%$ of the city's land area but contains $90 \%$ of the population of the city [35].

There are 473.7 square kilometers of cropland spread throughout the other four development zones. This mainly includes the coastal recreation corridor zone, the port and harbor value-added planning and management zone, the technology innovation corridor zone, and the slow easy lifestyle zone. It is obvious that there is great population pressure on the urban district and unbalanced development between the rural and urban districts. Thus, the city is confronted with a transition issue for further development. The size of cropland obviously exceeds that of urban open space. However, no attention has been paid to the existence of cropland, resulting in much cropland being shifted to other purposes. Illegally switching to manufacturing facilities is the most common phenomenon, resulting 
in high-quality cropland mixed with factories. This causes unexpected pollution damage to the vegetation and makes land planning difficult.

Under the NSLPA guidelines, land planning for Kaohsiung mainly focuses on the concept of "one core, two centers, and three axes". "One core" refers to the development of the economic and business core for the old district of the city. The "two centers" are the development of the northern part of the city, mainly for living, production, and tourism. The "three axes" refer to forest and agricultural production, industrial innovation, and coastal value added. The new arrangement of the six new development zones presented above is shown in Figure 2 [36].

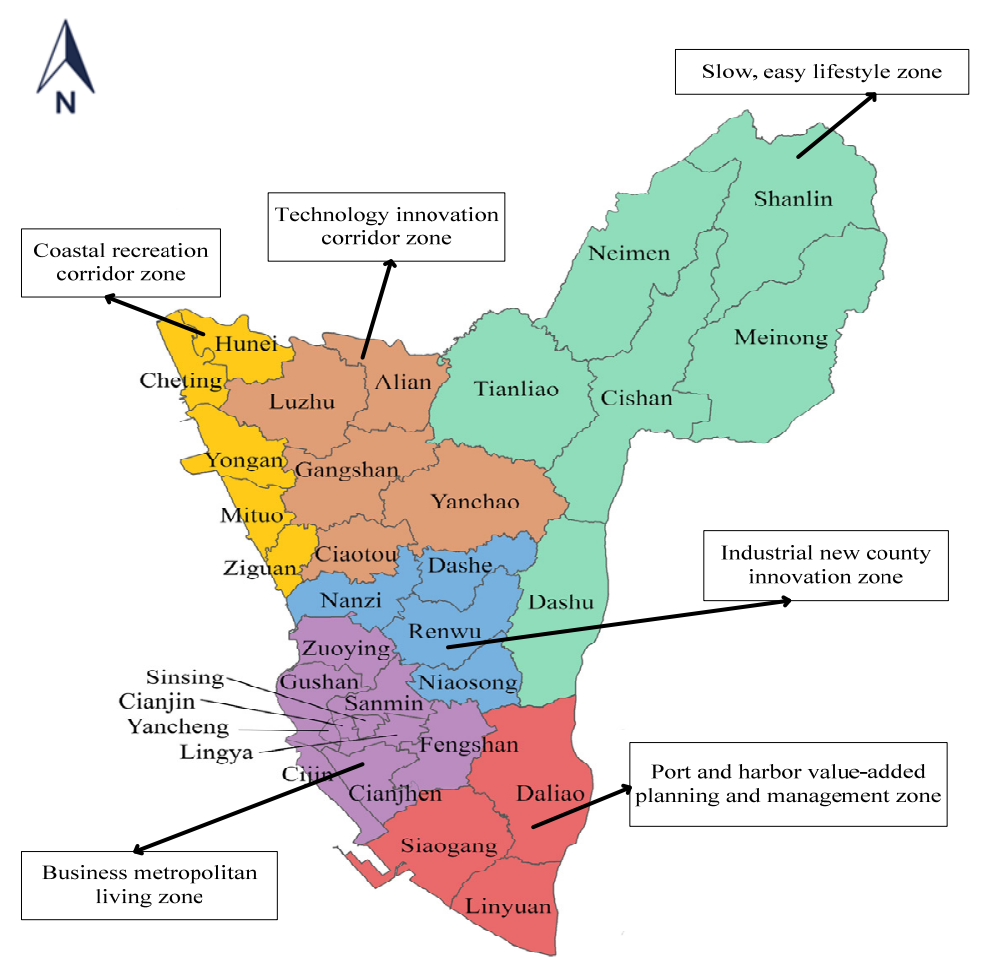

Figure 2. Development zones for Kaohsiung under National Spatial Land Planning Act.

Along with the development of each zone, different types of public facilities have been promoted and installed by various acts since 1978. These acts encourage Kaohsiung's establishment of facilities such as public libraries, cultural institutions, gas stations, circuit towers and substations, cemeteries, landfills, and sewage treatment facilities adjacent to urban open space or cropland. YIMBY facilities are normally located in the core area of an urban division, and NIMBY facilities are on the fringes or outside of an urban division. Public facilities such as Weiwuying National Kaohsiung Center for the Arts and various public libraries that have been constructed within the past 10 years are typical examples.

\subsection{Spatial Durbin Hedonic Price Model}

Open space has multifunctional value. However, there is no market to reflect the usage value gained by people. Thus, the value of open space should be evaluated by nonmarket evaluation methods, such as the commonly used hedonic price method (HPM). Rosen [37] provided a theoretical background for the HPM, and McConnell and Walls [28] reviewed many studies of various types of nonmarket goods using the HPM. The differentiation of housing prices is a composition of the dissimilar characteristics of housing and its surrounding characteristics. Housing characteristics can be specifically divided into the structures, surrounding characteristics, and natural or environmental specialties of housing. Thus, the concept of hedonic price seeks to maximize the utility function as (1) and thus 
derive the marginal implicit price of a specific attribute of housing. The utility for a specific consumer $k$ gained from the purchase of a housing unit is expressed as (1) below:

$$
U_{k}=U(G, H, N, S),
$$

where $U_{k}$ is the utility $k$ that the consumer gains from purchasing a specific housing unit. $G$ is a vector consumed other than housing, $\boldsymbol{H}$ is a vector of housing structures, $\boldsymbol{N}$ is a vector of housing surrounding characteristics, and $S$ is a vector of special characteristics such as NIMBY or YIMBY facilities for a specific housing unit. Under utility maximization, the equilibrium price of housing $i$ is written as (2):

$$
P_{i}=f_{i}(H, N, S)+\varepsilon_{i},
$$

All transacted housing normally has a problem of spatial dependence, either the existence of autocorrelation or spatial heterogeneity of the independent variable of housing prices or the dependent variables of all types of housing attributes. The value of Moran's $\mathrm{I}$ is used to determine the degree of spatial dependence among housing prices and any housing characteristics $\boldsymbol{H}, \boldsymbol{N}$, or $\boldsymbol{S}$, designated as $\boldsymbol{X}[24,38]$. If there is spatial dependence for any independent variables, then $\gamma_{k}$ is the lag for those variables, denoted as $\boldsymbol{W X}$. The spatial Durbin model (SDM) was developed to correct the dependence occurring in both transacted housing prices and any housing characteristics [24]. $W X_{k}$ is used to explain the spillover effect of independent variables with spatial dependence. SDM is as in (3) below $[24,39,40]$ :

$$
P_{i}=\rho W P_{i}+\beta_{0}+\boldsymbol{\beta}_{\boldsymbol{H}} \boldsymbol{H}+\boldsymbol{\beta}_{\boldsymbol{N}} \boldsymbol{N}+\boldsymbol{\beta}_{S} \boldsymbol{S}+\gamma_{\boldsymbol{k}} \boldsymbol{W} \boldsymbol{X}_{\boldsymbol{k}}+\varepsilon_{i}, \varepsilon_{i} \stackrel{i . i . d}{\sim} N\left(0, \sigma^{2}\right)
$$

The definitions of all the variables are the same as those stated above. Additionally, $W P_{i}$ is a spatial housing price-weighted matrix; $\rho$ is its corresponding coefficient; $\beta_{0}$ is the intercept term; $\beta_{H}, \beta_{N}$ and $\beta_{S}$ are the vectors of coefficients to be estimated for characteristics $H, N$, and $S$ stated above; $\varepsilon_{i}$ and is the error term.

The functional form (3) for SDM can further be rearranged as in Equation (4) below:

$$
\begin{gathered}
P_{i}=\left(I_{n}-\rho W\right)^{-1} \beta_{0}+\left(I_{n}-\rho W\right)^{-1}\left(\boldsymbol{\beta}_{H} \boldsymbol{H}+\boldsymbol{\beta}_{N} N+\boldsymbol{\beta}_{S} S+\gamma_{k} W X_{k}\right)+\left(I_{n}-\rho W\right)^{-1} \varepsilon_{i}, \\
\varepsilon_{i} \stackrel{i . i . d}{\sim} N\left(0, \sigma^{2} I_{n}\right),
\end{gathered}
$$

where $n$ is the number of housing units and $I_{n}$ is a matrix of $n \times n$. The marginal implicit price for a specific characteristic $X_{k}$ can be computed from (5). This is equivalent to the total impact from the change of a specific independent variable $k$ with spatial dependence on the housing price:

$$
\frac{\partial P}{\partial X_{k}}=\left(I_{n}-\rho W\right)^{-1}\left(I_{n} \beta_{k}+\gamma_{k} W\right)
$$

If the independent variable is not spatially dependent, then the total impact will be simplified to $(1-\rho)^{-1} \beta_{k}$. The marginal implicit price is treated as an indication of residents' willingness to pay (WTP) for a specific housing attribute $[4,40,41]$.

\subsection{Determination of the Impact Radius for Open Space with and without Adjacent NIMBY or YIMBY Facilities and Other Surrounding Characteristics}

The impact radius is used to determine the potential impact of NIMBY or YIMBY facilities on housing prices. A survey for this distance determination from a study was done by the authors of [12]. Some studies, such as Tsai et al. [10], Lai et al. [42], Wu et al. [40], Xue et al. [43], and Bai et al. [44] use the acceptable walking distance. However, the determination of the impact radius from the above methods lacks an empirical basis. Local polynomial regression was proposed by numerical evidence to determine the impact radius for a typical type of open space with or without NIMBY or YIMBY facilities on a transacted housing unit [27]. Local polynomial regression is a nonparametric analysis method using the means-square error to have the curve best fit the actual data $[45,46]$. 
Once the impact radius for NIMBY or YIMBY facility $\mathrm{f}$ on housing unit $\mathrm{A}, R_{A f}$ or any surrounding housing attribute is determined, the impact of any NIMBY or YIMBY facility on the housing unit is reflected by a proxy variable $\mathrm{SP}_{A f}\left(\mathrm{D}_{f}\right)$. Figure $3 \mathrm{~A}$ shows that the impact is the difference between the impact radius of $R_{A f}$, and the shortest distance between the housing unit and facility $f$ is $D_{f}$. That is, using a NIMBY or YIMBY facility as an example, a proxy variable representing the impact of a facility is represented as $\mathrm{SP}_{A f}\left(\mathrm{D}_{f}\right)=R_{A f}-D_{f}$ when the shortest distance is smaller than that of the impact radius. A facility might reinforce or weaken the impact of open space on housing prices by its total surrounding open space area. Under such circumstances, failure to take into account the impact of NIMBY or YIMBY facilities on housing might distort the influence of open space areas on housing prices. On the other hand, when the shortest distance between the transacted housing unit and the facility is larger than the impact radius, then the proxy variable of NIMBY or YIMBY, $\mathrm{SP}_{A f}\left(\mathrm{D}_{f}\right)$ is zero, as shown in Figure 3B.

The longer the shortest distance between a transacted housing unit and an open space with or without facilities is, the smaller the impact of the facility on the housing price is. There is no impact once the shortest distance is beyond the impact radius of the open space with NIMBY or YIMBY facilities. The impact radius $R_{A f}$ is found to be $1350 \mathrm{~m}$ for the distance between a specific housing unit and urban open space or cropland and any NIMBY or YIMBY facility. The proxy variable is represented as (6) below:

$$
\mathrm{SP}_{A f}\left(\mathrm{D}_{A}\right)= \begin{cases}1350-\mathrm{D}_{f}, & \mathrm{D}_{f}<1350 \\ 0, & \mathrm{D}_{f}>1350\end{cases}
$$

where $f$ is the transacted housing unit and $A$ indicates different types of open space with any NIMBY or YIMBY facility. Different impact boundaries for all other housing characteristics are determined in the same manner as in Equation (6). The results are listed in Table 1.

Table 1. Impact radius between housing unit and different adjacent YIMBY or NIMBY facilities for urban open space and cropland and surrounding spatial characteristics.

\begin{tabular}{|c|c|c|c|c|}
\hline Type of Open Space & Type of Facility & Kind of Facility & $\begin{array}{l}\text { Type of Open Space and } \\
\text { Its Adjacent Facilities }\end{array}$ & $\begin{array}{c}\text { Impact Radius } \\
\text { (m) }\end{array}$ \\
\hline \multicolumn{5}{|c|}{ Adjacent YIMBY or NIMBY Facilities } \\
\hline \multirow{6}{*}{$\begin{array}{l}\text { Open Space(urban } \\
\text { open spaces or } \\
\text { cropland) }\end{array}$} & \multirow[b]{2}{*}{ YIMBY } & 1. public library & \multirow{2}{*}{$\begin{array}{l}\text { urban open space with } \\
\text { adjacent public libraries } \\
\text { urban open space with } \\
\text { adjacent cultural } \\
\text { institutions }\end{array}$} & 1000 \\
\hline & & 2. cultural institutions & & 2400 \\
\hline & \multirow{3}{*}{ NIMBY } & $\begin{array}{l}\text { 3. gas stations, circuit } \\
\text { towers, and substations }\end{array}$ & \multirow{3}{*}{$\begin{array}{l}\text { urban open space with } \\
\text { adjacent gas stations, } \\
\text { circuit towers, and } \\
\text { substations } \\
\text { urban open space with } \\
\text { adjacent cemeteries } \\
\text { urban open space with } \\
\text { adjacent landfill and } \\
\text { sewage treatment plants }\end{array}$} & 250 \\
\hline & & 4. cemetery & & 600 \\
\hline & & $\begin{array}{l}\text { 5. landfill and sewage } \\
\text { treatment plant }\end{array}$ & & 2000 \\
\hline & & none of above five kinds & $\begin{array}{l}\text { urban open space without } \\
\text { any adjacent YIMBY or } \\
\text { NIMBY facilities }\end{array}$ & 1350 \\
\hline \multicolumn{5}{|c|}{ Housing surrounding characteristics } \\
\hline & convenience store & number of co & venience stores & 1350 \\
\hline & public transportation & mass rapid trar & it (MRT) stations & 1500 \\
\hline & & bus stops and pass & nger transport stops & 950 \\
\hline & School & primary, junior, an & senior high schools & 1050 \\
\hline & commercial institution & commercial b & nks, post offices & 1900 \\
\hline
\end{tabular}




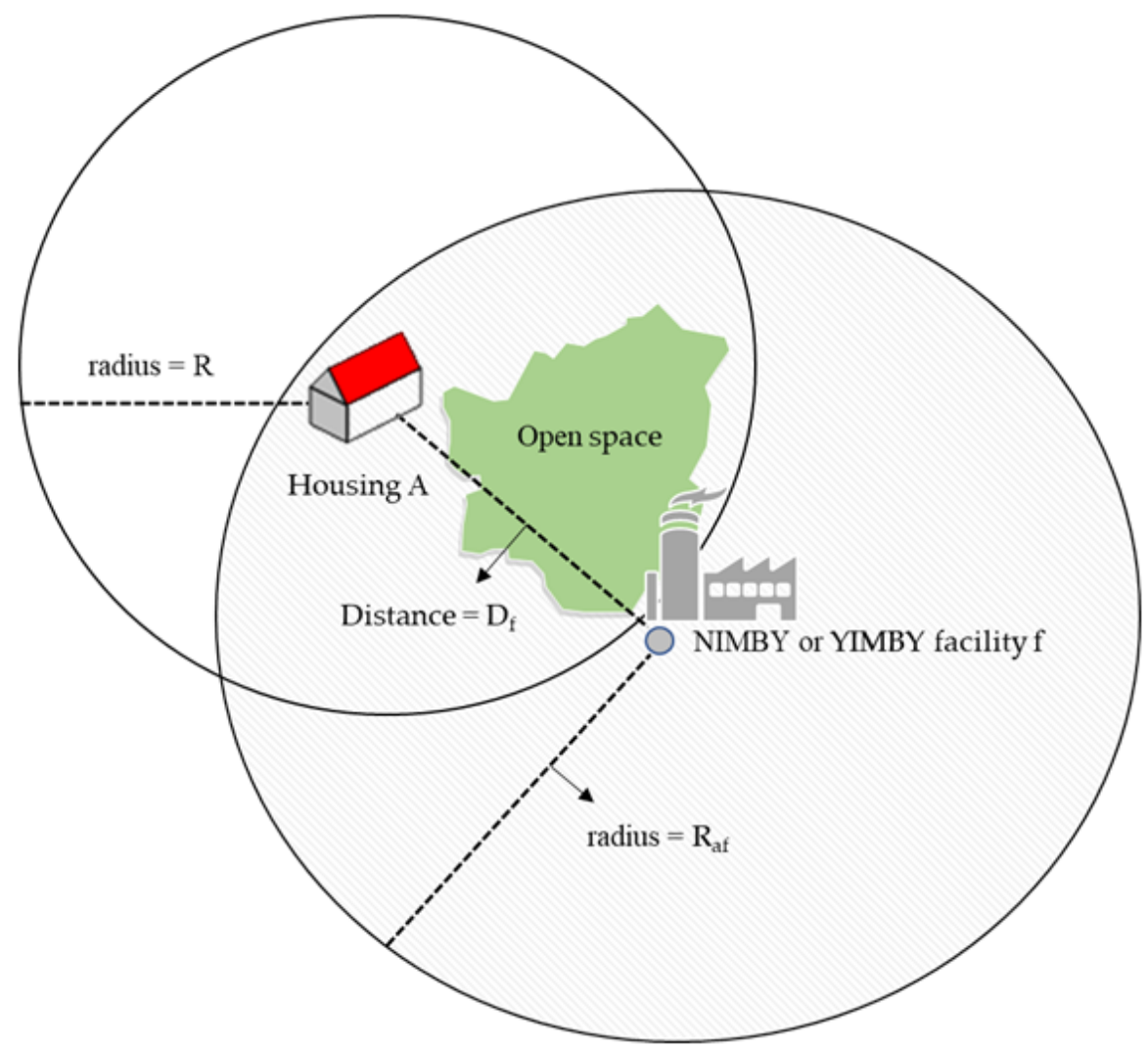

(A)

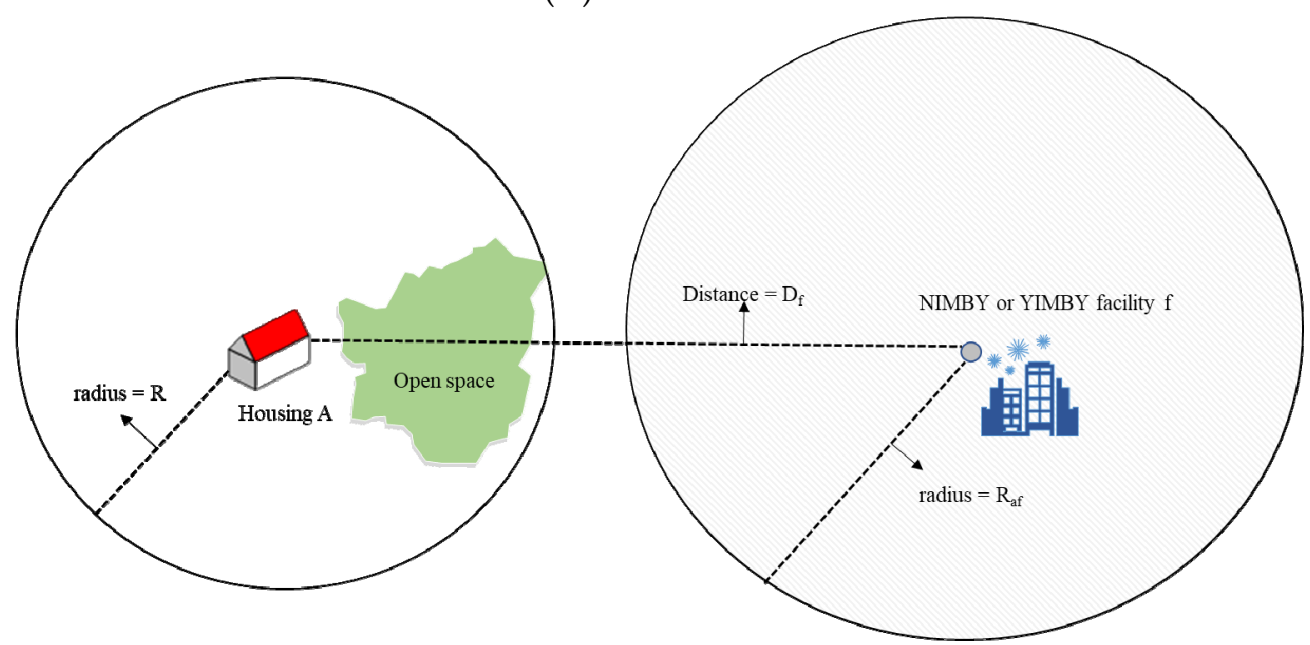

(B)

Figure 3. (A) Open space with a non-zero proxy variable of NIMBY or YIMBY facilities for a housing unit. (B) Open space with a zero proxy variable of NIMBY or YIMBY facilities for a housing unit.

\section{Data Sources, Variable Selection, and Treatments}

\subsection{Sources of Transacted Housing Data}

To evaluate the benefit of urban open space and cropland with and without NIMBY or YIMBY facilities, a set of data for housing transactions in Kaohsiung is required. The data are obtained from the "Web Service of Actual Real Transactions of Real Estate" prepared by the Ministry of the Interior from 1 August 2012 to 30 June 2018 [47]. The original data comprise 98,192 transacted housing units with complete attributes required in the analyses. Among these, 13,460 transactions are deleted because they are not for residential housing purposes and are the top $1 \%$ and bottom $1 \%$ housing-price outliers [26]. The final number of transactions is 84,732 . Since all transacted housing prices are the nominal price of each 
year, the potential for price inflation must be taken into account. Thus, all the transacted housing data recorded from 1 August 2012 to 30 June 2018 are deflected by the housing price index of Kaohsiung in 2016. The advantage of using the housing price index for Kaohsiung compared to the consumer price index is that the housing price index reflects the housing differentials among cities.

\subsection{Variable Selection and Treatment}

Three categories of characteristics have a potential impact on housing prices. One category is housing structures. This includes the total number of floors of the building, the floor that a specific transacted housing unit is on (floor), the size of the transacted housing (housearea), the age of the transacted housing (age), the number of living rooms (hall), the number of bathrooms (bath), and whether the housing includes a parking space (Dparking) [10,48]. Previous studies indicate that housing prices vary by the type of housing [39]. Thus, five types of housing are included: "large building of 10 or more floors with elevator(s) (Dtype1)", "building of nine or fewer floors with elevator(s) (Dtype2)", "apartment of five or fewer floors without elevator (Dtype3)", "townhouse (Dtype4)", and "studio apartment with one room, one bathroom, and one living room (Dtype5)". The housing age is the difference between the completion date of construction and the housing transaction date, measured in years.

There are six development zones under Kaohsiung's NSLPA. Among these six zones, the business metropolitan living zone is a high-urbanization area. All the other areas are urban and rural mixed areas and have multiple development nuclei. Thus, the following analyses are conducted for the business zone as one type with a dummy variable $D d 1=1$ used to represent the housing units located in this zone. In contrast, a dummy variable $D d 1^{\prime}=1$ for the other five development zones is used as the other group. The urban open space in these six zones includes urban parks, squares, green spaces, playgrounds, and gymnasium land use in the urban planning district; recreational areas in the non-urban planning district and cropland are mainly in the non-urban planning district [35].

With regard to the category of YIMBY or NIMBY facilities, YIMBY facilities include public libraries and cultural institutes, while NIMBY facilities include gas stations, circuit towers and substations, cemeteries, and landfill and sewage treatment plants. All facilities use June 2018 data with TWD97 coordinates for specific locations [49]. With the spatial join tool in the geographic information systems (GIS) by ArcMap, the impact radius of five types of adjacent NIMBY or YIMBY facilities is found for urban open space and cropland, respectively. The impact radius for a transacted housing unit of $1350 \mathrm{~m}$ for either type of open space with any adjacent YIMBY or NIMBY facility is listed in Table 1.

Impact boundaries are also determined for all types of housing surrounding spatial characteristics, that is, MRT stations $(S P(M R T))$; primary, junior, or senior high schools $(S P(S c h))$; financial institutions $(S P(B a n k))$; and bus stops $(S P(B u s))$. The impacts of characteristics surrounding housing are reflected by their proxy variable SP. The ubiquitous convenience stores play various functions in Taiwan. They enable shopping for goods and serve as a one-stop center for all types of fee payments, cash withdrawals and deposits, and mail and parcel delivery. Thus, the number of convenience stores belonging to the four largest chains within an impact radius for a specific transacted housing unit, variable $(4 c m k t)$, is measured. The number of convenience stores within $1350 \mathrm{~m}$ of each transacted housing unit is 28.92. All notations, definitions, and the mean value of each attribute in the estimation are listed in Table 2. 
Table 2. Notations, definitions, and mean values of all the variables used in the estimation.

\begin{tabular}{|c|c|c|c|}
\hline Variable & Definition & Mean & Standard Error \\
\hline \multicolumn{4}{|c|}{ Independent Variable } \\
\hline Price & transacted housing price (TWD) & $8,192,354$ & $7,548,467$ \\
\hline \multicolumn{4}{|c|}{ Housing structures } \\
\hline Age & age of the transacted housing (year) & 14.37 & 12.22 \\
\hline Floor & floor of the transacted unit & 6.92 & 4.89 \\
\hline Housearea & total transacted area $\left(\mathrm{m}^{2}\right)$ & 149.44 & 81.16 \\
\hline Hall & number of living rooms & 1.74 & 0.61 \\
\hline Bath & number of bathrooms & 2.11 & 1.21 \\
\hline Dparking & dummy variable, 1 if the transacted housing has a parking space, 0 if not & 0.386 & 0.487 \\
\hline Dtype ${ }^{*}$ & dummy variable, 1 if housing is a large building of 10 or more floors; 0 otherwise & 0.561 & 0.496 \\
\hline Dtype2 & dummy variable, 1 if housing is a large building of 9 or fewer floors; 0 otherwise & 0.075 & 0.263 \\
\hline Dtype3 & dummy variable, 1 if housing is an apartment; 0 otherwise & 0.052 & 0.222 \\
\hline Dtype 4 & dummy variable, 1 if housing is a townhouse; 0 otherwise & 0.278 & 0.448 \\
\hline Dtype5 & dummy variable, 1 if housing is a studio apartment; 0 otherwise & 0.034 & 0.181 \\
\hline \multicolumn{4}{|c|}{ Housing surrounding characteristics } \\
\hline$S P(M R T)$ & $\begin{array}{c}\text { distance, if distance between the transacted housing unit and the nearest MRT } \\
\text { station is over } 1100 \mathrm{~m} \text {, then } S P(M R T)=0 \text {; otherwise, } S P(M R T)=(1500 \text { - the } \\
\text { distance between the two })(\mathrm{m})\end{array}$ & 421.48 & 475.35 \\
\hline$S P(B u s)$ & $\begin{array}{c}\text { distance, if distance between the transacted housing unit and the nearest bus stop } \\
\text { is over } 950 \mathrm{~m} \text {, then } \mathrm{SP}(\text { Bus })=0 \text {; otherwise, } \mathrm{SP}(B u s)=\text { (950-the distance } \\
\text { between the two })(\mathrm{m})\end{array}$ & 795.43 & 148.93 \\
\hline$S P(S c h)$ & $\begin{array}{l}\text { distance, if distance between the transacted housing unit and the nearest primary, } \\
\text { junior, or senior high school is over } 1050 \mathrm{~m} \text {, then } \mathrm{SP}(S c h)=0 \text {; otherwise, } \\
\qquad \mathrm{SP}(S c h)=(1050 \text {-the distance between the two })(\mathrm{m})\end{array}$ & 623.29 & 225.70 \\
\hline SP(Bank) & $\begin{array}{l}\text { distance, if distance between the transacted housing unit and the nearest } \\
\text { commercial institution is over } 1900 \mathrm{~m} \text {, then } \mathrm{SP}(\text { Bank })=0 \text {; otherwise, } \\
\operatorname{SP}(\text { Bank })=(1900 \text {-the distance between the two })(\mathrm{m})\end{array}$ & 1456.41 & 419.58 \\
\hline $4 c m k t$ & number of convenience stores within a $1350-\mathrm{m}$ radius of a transacted housing unit & 28.92 & 18.52 \\
\hline$D d 1$ & dummy variable, 1 if the zone is a business metropolitan living zone, 0 if not & 0.627 & 0.484 \\
\hline$D d 1^{\prime}$ & dummy variable, 1 if the zone is not a business metropolitan living zone, 0 if not & 0.373 & 0.484 \\
\hline \multicolumn{4}{|c|}{ NIMBY and YIMBY facilities } \\
\hline$D 1$ & $\begin{array}{c}\text { dummy variable, } 0 \text { if the distance between the transacted housing unit and the } \\
\text { nearest public library is over } 1000 \mathrm{~m} ; 1 \text { otherwise }\end{array}$ & 0.519 & 0.500 \\
\hline D2 & $\begin{array}{l}\text { dummy variable, } 0 \text { if the distance between the transacted housing unit and the } \\
\text { nearest cultural institution is over } 2400 \mathrm{~m} ; 1 \text { otherwise }\end{array}$ & 0.736 & 0.441 \\
\hline D3 & $\begin{array}{l}\text { dummy variable, } 0 \text { if the distance between the transacted housing unit and the } \\
\text { nearest gas station, circuit tower, or substation is over } 250 \mathrm{~m}, 1 \text { otherwise }\end{array}$ & 0.190 & 0.392 \\
\hline$D 4$ & $\begin{array}{c}\text { dummy variable, } 0 \text { if the distance between the transacted housing unit and the } \\
\text { nearest cemetery is over } 600 \mathrm{~m}, 1 \text { otherwise }\end{array}$ & 0.054 & 0.227 \\
\hline D5 & $\begin{array}{l}\text { dummy variable, } 0 \text { if the distance between the transacted housing unit and the } \\
\text { nearest landfill and sewage treatment plant is over } 2000 \mathrm{~m}, 1 \text { otherwise } \\
\text { proxy variable, if the distance between the transacted housing unit and the nearest }\end{array}$ & 0.207 & 0.405 \\
\hline$S P\left(O S_{1}\right)$ & $\begin{array}{l}\text { urban open space with adjacent public libraries is over } 1000 \mathrm{~m} \text {, then } S P\left(O S_{1}\right)=0 \text {; } \\
\text { otherwise, } S P\left(O S_{1}\right)=(1000 \text {-distance between the two })(\mathrm{m})\end{array}$ & 167.15 & 264.99 \\
\hline$S P\left(\mathrm{OS}_{2}\right)$ & $\begin{array}{l}\text { proxy variable, if the distance between the transacted housing unit and the nearest } \\
\text { urban open space with adjacent cultural institutions is over } 2400 \mathrm{~m} \text {, then } \\
S P\left(O S_{2}\right)=0 \text {; otherwise, } P\left(O S_{2}\right)=(2400 \text {-distance between the two })(\mathrm{m})\end{array}$ & 1044.88 & 823.22 \\
\hline$S P\left(O S_{3}\right)$ & $\begin{array}{l}\text { proxy variable, if the distance between the transacted housing unit and the nearest } \\
\text { urban open space with adjacent gas stations, circuit towers, and substations is over } \\
250 \mathrm{~m} \text {, then } S P\left(O S_{3}\right)=0 \text {; otherwise } S P\left(O S_{3}\right)=(250 \text {-distance between the two })(\mathrm{m})\end{array}$ & 17.98 & 49.92 \\
\hline$S P\left(O_{4}\right)$ & $\begin{array}{l}\text { proxy variable, if the distance between the transacted housing unit and the nearest } \\
\text { urban open space with adjacent cemeteries is over } 600 \mathrm{~m} \text {, then } S P\left(O S_{4}\right)=0 \text {; } \\
\text { otherwise } S P\left(\mathrm{OS}_{4}\right)=(600 \text {-distance between the two }(\mathrm{m})\end{array}$ & 10.10 & 58.75 \\
\hline
\end{tabular}


Table 2. Cont.

\begin{tabular}{|c|c|c|c|}
\hline Variable & Definition & Mean & Standard Error \\
\hline$S P\left(\mathrm{OS}_{5}\right)$ & $\begin{array}{l}\text { proxy variable, if the distance between the transacted housing unit and the nearest } \\
\text { urban open space with adjacent landfills and sewage treatment plants is over } \\
2000 \mathrm{~m} \text {, then } S P\left(O S_{5}\right)=0 \text {; otherwise } S P\left(O S_{5}\right)=(2000 \text {-distance between the two })(\mathrm{m})\end{array}$ & 53.67 & 237.38 \\
\hline$S P\left(O_{6}\right)$ & $\begin{array}{l}\text { proxy variable, it the distance between the transacted housing unit and the nearest } \\
\text { urban open space without any adjacent NIMBY or YIMBY facilities is over } 1350 \mathrm{~m} \text {, } \\
\text { then } S P\left(\mathrm{OS}_{6}\right)=0 \text {; otherwise } S P\left(\mathrm{OS}_{6}\right)=(1350 \text {-distance the two })(\mathrm{m})\end{array}$ & 1173.05 & 176.19 \\
\hline$S P\left(A G_{1}\right)$ & $\begin{array}{l}\text { proxy variable, if the distance between the transacted housing unit and the nearest } \\
\text { cropland with adjacent public libraries is over } 1000 \mathrm{~m} \text {, then } \operatorname{SP}\left(A G_{1}\right)=0 \text {; } \\
\text { otherwise } \operatorname{SP}\left(A G_{1}\right)=(1000 \text {-distance between the two })(\mathrm{m})\end{array}$ & 7.10 & 62.06 \\
\hline$S P\left(A G_{2}\right)$ & $\begin{array}{l}\text { proxy variable, if the distance between the transacted housing unit and the nearest } \\
\text { cropland with adjacent cultural institutions is over } 2400 \mathrm{~m} \text {, then } \operatorname{SP}\left(A G_{2}\right)=0 \text {; } \\
\text { otherwise } S P\left(A G_{2}\right)=(2400 \text {-distance between the two }(\mathrm{m})\end{array}$ & 16.40 & 129.12 \\
\hline$S P\left(A G_{3}\right)$ & $\begin{array}{l}\text { proxy variable, if the distance between the transacted housing unit and the nearest } \\
\text { cropland with adjacent gas stations, circuit towers, and substations is over } 250 \mathrm{~m} \text {, } \\
\text { then } S P\left(A G_{3}\right)=0 \text {; otherwise } S P\left(A G_{3}\right)=(250 \text {-distance between the two }(\mathrm{m})\end{array}$ & 4.94 & 26.02 \\
\hline$S P\left(A G_{4}\right)$ & $\begin{array}{l}\text { proxy variable, if the distance between the transacted housing unit and the nearest } \\
\text { cropland with adjacent cemeteries is over } 600 \mathrm{~m} \text {, then } S P\left(A G_{4}\right)=0 \text {; otherwise } \\
\qquad S P\left(A G_{4}\right)=(600 \text {-distance between the two }(\mathrm{m})\end{array}$ & 19.22 & 83.18 \\
\hline$S P\left(A G_{5}\right)$ & $\begin{array}{l}\text { proxy variable, if the distance between the transacted housing unit and the nearest } \\
\text { cropland with adjacent landfills and sewage treatment plants is over } 2000 \mathrm{~m} \text {, then } \\
\qquad S P\left(A G_{5}\right)=0 \text {; otherwise } S P\left(A G_{5}\right)=(2000 \text {-distance between the two }(\mathrm{m})\end{array}$ & 48.80 & 219.05 \\
\hline$S P\left(A G_{6}\right)$ & $\begin{array}{l}\text { proxy variable, if the distance between the transacted housing unit and the nearest } \\
\text { cropland without adjacent NIMBY or YIMBY facilities is over } 1350 \mathrm{~m} \text {, then } \\
\quad S P\left(A G_{6}\right)=0 \text {; otherwise } S P\left(A G_{6}\right)=(1350 \text {-distance between the two }(\mathrm{m})\end{array}$ & 777.84 & 434.18 \\
\hline OSArea & Area of urban open space within $1350-\mathrm{m}$ radius of a transacted housing unit $\left(\mathrm{m}^{2}\right)$ & 269,524 & 128,394 \\
\hline AGArea & Area of cropland within $1350-\mathrm{m}$ radius of a transacted housing unit $\left(\mathrm{m}^{2}\right)$ & 258,863 & 457,912 \\
\hline
\end{tabular}

Note *: The reference housing type is type1, a large building of 10 or more floors.

\section{Evaluation Results and Discussion}

\subsection{Model Specification}

The log transformation of dependent housing prices can not only reduce the impact of extreme values but also reduce possible heteroscedasticity. Moreover, the change in the transformed variable can be explained as a percentage change to avoid the impact of different unit measurements [4]. A similar transformation is applied to the independent variable, the transacted housing price. This is a mixed log-linear function appropriate for the characteristics of the data [50]. The value of Moran's I among housing prices is 0.657 . The age of the transacted housing unit (age) and townhouse type 4 housing (Dtype4) have a Moran's I of 0.6. This means that the SDM model in (7) is appropriate for estimation:

$$
\begin{aligned}
& \text { Inprice }_{i}=\rho W \_ \text {Inprice }_{i}+\alpha_{0}+\alpha_{1} \text { Age } e_{i}+\gamma_{1} W_{-} \text {Age } e_{i}+\alpha_{2} \text { Floor }_{i}+\alpha_{3} \text { lnhousearea }_{i}+\alpha_{4} \text { Hall }_{i} \\
& +\alpha_{5} \text { Bath }_{i}+\alpha_{6} \text { D parking }_{i}+\sum_{T=2}^{5} \alpha_{5+T} \text { Dtype }_{T i}+\gamma_{2} W_{-} \text {Dtype }_{i}+\alpha_{11}[\ln S P(M R T)]_{i}^{2} \\
& +\alpha_{12}[\ln S P(B u s)]_{i}^{2}+\alpha_{13}[\ln S P(S c h)]_{i}^{2}+\alpha_{14}[\ln S P(B a n k)]_{i}^{2}+\alpha_{15} 4 c m k t_{i} \\
& +\sum_{F=1}^{6} \alpha_{15+F}\left[\ln S P\left(O S_{F}\right)\right]_{i}^{2} \times D d 1+\alpha_{22} \ln O S \text { Area } \times D d 1^{\prime}+\varepsilon_{i} \\
& +\sum_{F=1}^{5} \alpha_{22+F} D_{F} \times \operatorname{lnOSArea} \times D d 1+\sum_{F=1}^{6} \alpha_{27+F} \ln S P\left(O S_{F}\right) \times D d 1^{\prime}+\alpha_{34}[\ln O S \text { Area }]_{i}^{2} \times D d 1^{\prime} \\
& +\sum_{F=1}^{5} \alpha_{34+F} D_{F} \times[\operatorname{lnOSArea}]_{i}^{2} \times D d 1^{\prime}+\sum_{F=3}^{6} \alpha_{37+F} \ln S P\left(A G_{F}\right)^{2} \times D d 1+\alpha_{44}[\ln A G A r e a] \times D d 1 \\
& +\sum_{F=1}^{5} \alpha_{44+F} D_{F} \times[\ln A G A r e a]_{i}^{2} \times D d 1+\sum_{F=1}^{6} \alpha_{49+F}\left[\ln S P\left(A G_{F}\right)\right]_{i}^{2} \times D d 1^{\prime} \\
& \left.+\alpha_{56}[\ln A G \text { Area })\right]_{i}^{2} \times D d 1^{\prime}+\sum_{F=1}^{5} \alpha_{56+F} D_{F} \times[\ln A G \text { Area }]_{i}^{2} \times D d 1^{\prime}, \quad i=1, \ldots, 84,732
\end{aligned}
$$

In (7), $i$ indicates the transacted housing unit, $\alpha_{0}$ is the constant, $\alpha_{1}$ to $\alpha_{61}$ are the coefficients to be estimated, and $\varepsilon_{i}$ is the error term. W_lnprice ${ }_{i}$ is log housing prices, and 
$\rho$ is the corresponding coefficient to be estimated. Similarly, $W \_A g e_{i}$ and $W \_D t y p e 4_{i}$ are the lag housing age and lag housing type 4 with spatial dependence, and $\gamma_{1}$ and $\gamma_{2}$ are the corresponding coefficients to be estimated for these two lag independent variables.

\subsection{Estimation Results and Discussion}

\subsubsection{Estimated Coefficients}

The estimated results of Equation (7) are listed in Table 3. Various values for the fitness of models AIC, SC, LIK, and LR test are significant, which indicates that SDM is a good fit for the data at hand. The signs for the estimated coefficients of characteristics surrounding housing, that is, the distance between the transacted housing and the nearest MRT station $(S P(M R T))$, the nearest bus stop $(S P(B u s))$, the nearest compulsory school $(S P(S c h))$, and the nearest commercial institution $(S P(B a n k))$, as well as the number of convenience stores within a buffer of $1350 \mathrm{~m}(4 \mathrm{cmkt})$, all have positive and significant estimated coefficients.

Table 3. Results of coefficient estimations *.

\begin{tabular}{|c|c|c|c|c|}
\hline \multirow{2}{*}{$\begin{array}{c}\text { Variable } \\
W \text { lnprice }\end{array}$} & \multicolumn{2}{|c|}{ Estimated Coefficient } & \multirow{2}{*}{$\begin{array}{c}\text { Standard Error } \\
0.00295878\end{array}$} & \multirow{2}{*}{$\begin{array}{c}\text { Wald } \\
16,564.46221\end{array}$} \\
\hline & 0.380802 & $* * *$ & & \\
\hline Constant & 5.42347 & $* * *$ & 0.0413948 & $17,165.71632$ \\
\hline Age & -0.0145034 & $* * *$ & 0.00017247 & 7071.53174 \\
\hline W_age & 0.00673155 & $* * *$ & 0.000224525 & 898.87835 \\
\hline Floor & 0.000817 & $* * *$ & 0.00022822 & 12.81554 \\
\hline Lnhousearea & 0.697074 & $* * *$ & 0.00328231 & $45,102.29113$ \\
\hline Hall & 0.00818594 & $* * *$ & 0.00168727 & 23.53802 \\
\hline Bath & 0.021167 & $* * *$ & 0.00111042 & 363.36366 \\
\hline Dparking & 0.126596 & $* * *$ & 0.00253552 & 2492.91503 \\
\hline Dtype2 & -0.0716361 & $* * *$ & 0.00382786 & 350.22877 \\
\hline Dtype3 & -0.0729824 & $* * *$ & 0.00497689 & 215.04170 \\
\hline Dtype 4 & 0.688532 & $* * *$ & 0.00523398 & $17,305.40251$ \\
\hline W_Dtype4 & -0.436791 & $* * *$ & 0.00610564 & 5117.82852 \\
\hline Dtype5 & -0.12578 & $* * *$ & 0.00573284 & 481.37676 \\
\hline$[\ln S P(M R T)]^{2}$ & 0.000852354 & $* * *$ & 0.0000639 & 178.03565 \\
\hline$[\ln S P(B u s)]^{2}$ & 0.0005404 & $* * *$ & 0.000192939 & 7.84498 \\
\hline$[\ln S P(S c h)]^{2}$ & 0.0017423 & $* * *$ & 0.000130488 & 178.27857 \\
\hline$[\ln S P(\text { Bank })]^{2}$ & 0.00226029 & $* * *$ & 0.000136898 & 272.60652 \\
\hline $4 c m k t$ & 0.00249478 & $* * *$ & 0.0001 & 622.43763 \\
\hline $\operatorname{lnSP}\left(O S_{1}\right) x D d 1$ & 0.000162892 & $* *$ & 0.0000765 & 4.52975 \\
\hline $\operatorname{lnSP}\left(\mathrm{OS}_{2}\right) x \mathrm{Dd} 1$ & 0.00154519 & $* * *$ & 0.000084 & 338.61888 \\
\hline $\operatorname{lnSP}\left(\mathrm{OS}_{3}\right) x \mathrm{Dd} 1$ & -0.000510479 & $* * *$ & 0.000132088 & 14.93583 \\
\hline $\operatorname{lnSP}\left(\mathrm{OS}_{4}\right) x \mathrm{Dd1}$ & 0.0000571 & & 0.000176872 & 0.10436 \\
\hline $\ln S P\left(O S_{5}\right) x D d 1$ & -0.00258501 & $* * *$ & 0.000489612 & 27.87534 \\
\hline $\ln S P\left(O S_{6}\right) x D d 1$ & 0.00566217 & $* * *$ & 0.000483972 & 136.87596 \\
\hline $\operatorname{lnOSAreaxDd1}$ & 0.00184148 & $* * *$ & 0.000157554 & 136.60701 \\
\hline$D_{1} \times \ln O S A r e a \times D d 1$ & 0.000191414 & $* * *$ & 0.0000322 & 35.37406 \\
\hline$D_{2} \times \ln O S A r e a x D d 1$ & -0.000258577 & $* *$ & 0.00010281 & 6.32563 \\
\hline$D_{3} \times \ln O S A$ rea $x d 1$ & 0.0000332 & & 0.0000336 & 0.97462 \\
\hline$D_{4} \times \ln O S A r e a x D d 1$ & 0.00155578 & $* * *$ & 0.000413608 & 14.14881 \\
\hline$D_{5} \times \ln O S A r e a x D d 1$ & -0.000711574 & $* * *$ & 0.0000577 & 151.96972 \\
\hline $\ln S P\left(O S_{1}\right) \times D d 1^{\prime}$ & -0.000217308 & $* *$ & 0.000098 & 4.91261 \\
\hline $\ln S P\left(O S_{2}\right) \times D d 1^{\prime}$ & -0.00146097 & $* * *$ & 0.000187439 & 60.75205 \\
\hline $\ln S P\left(O S_{3}\right) \times D d 1^{\prime}$ & -0.00039787 & $* * *$ & 0.000089 & 19.96436 \\
\hline $\ln S P\left(O S_{4}\right) \times D d 1^{\prime}$ & -0.000349813 & $* * *$ & 0.000122927 & 8.09795 \\
\hline $\ln S P\left(O S_{5}\right) \times D d 1^{\prime}$ & -0.00461275 & $* * *$ & 0.000273059 & 285.37007 \\
\hline
\end{tabular}


Table 3. Cont.

\begin{tabular}{|c|c|c|c|c|}
\hline Variable & \multicolumn{2}{|c|}{ Estimated Coefficient } & \multirow{2}{*}{$\begin{array}{c}\text { Standard Error } \\
0.000317801\end{array}$} & \multirow{2}{*}{$\begin{array}{c}\text { Wald } \\
96.504689\end{array}$} \\
\hline $\ln S P\left(O S_{6}\right) \times D d 1^{\prime}$ & -0.0031219833 & $* * *$ & & \\
\hline$[\ln O S A r e a]^{2} x D d 1^{\prime}$ & 0.00285553 & $* * *$ & 0.000106547 & 718.27752 \\
\hline$D_{1} \times[\ln O S A \text { rea }]^{2} \times D d 1^{\prime}$ & 0.000296407 & $* * *$ & 0.0000847 & 12.26022 \\
\hline$D_{2} \times[\ln O S A r e a]^{2} \times D d 1^{\prime}$ & 0.000446687 & $* * *$ & 0.0000777 & 33.08827 \\
\hline$D_{3} \times[\ln O S A r e a]^{2} \times D d 1^{\prime}$ & 0.000082 & & 0.0000848 & 0.934138 \\
\hline$D_{4} \times[\ln O S A r e a]^{2} \times D d 1^{\prime}$ & -0.00101559 & $* * *$ & 0.000123326 & 67.81499 \\
\hline$D_{5} \times[\ln O S A r e a]^{2} \times D d 1^{\prime}$ & 0.0001843 & $* *$ & 0.0000921 & 4.00656 \\
\hline $\ln S P\left(A G_{3}\right)^{2} \times D d 1$ & 0.000904528 & $* * *$ & 0.000189711 & 22.73316 \\
\hline $\ln S P\left(A G_{4}\right)^{2} \times D d 1$ & -0.00410063 & $* * *$ & 0.000555846 & 54.42426 \\
\hline $\ln S P\left(A G_{5}\right)^{2} \times D d 1$ & 0.00223932 & $* * *$ & 0.000523593 & 18.29127 \\
\hline $\ln S P\left(A G_{6}\right)^{2} \times D d 1$ & 0.000100029 & & 0.000156611 & 0.40795 \\
\hline [lnAGArea]xDd1 & 0.0000216 & & 0.000130005 & 0.02768 \\
\hline$D_{1} x[\ln A G A \text { rea }]^{2} x D d 1$ & -0.000498222 & $* * *$ & 0.0000565 & 77.69100 \\
\hline$D_{2} x[\ln A G A r e a]^{2} x D d 1$ & 0.0000398 & & 0.000127886 & 0.09706 \\
\hline$D_{3} x[\ln A G A r e a]^{2} \times D d 1$ & -0.000195437 & $* * *$ & 0.00006 & 10.597890 \\
\hline$D_{4} x[\ln A G A r e a]^{2} x D d 1$ & -0.00208824 & $* * *$ & 0.000526233 & 15.74725 \\
\hline$D_{5} x[\ln A G A r e a]^{2} x D d 1$ & 0.000768678 & $* * *$ & 0.0000855 & 80.83592 \\
\hline$\left[\ln S P\left(A G_{1}\right)\right]^{2} \times D d 1^{\prime}$ & -0.000329351 & $* * *$ & 0.000178985 & 3.38597 \\
\hline$\left[\ln S P\left(A G_{2}\right)\right]^{2} \times D d 1^{\prime}$ & 0.00147316 & $* * *$ & 0.000431797 & 11.63967 \\
\hline$\left[\ln S P\left(A G_{3}\right)\right]^{2} \times D d 1^{\prime}$ & 0.000209611 & $* *$ & 0.000102502 & 4.18178 \\
\hline$\left[\ln S P\left(A G_{4}\right)\right]^{2} \times D d 1^{\prime}$ & 0.00034216 & $* * *$ & 0.000107654 & 10.10185 \\
\hline$\left[\ln S P\left(A G_{5}\right)\right]^{2} x D d 1^{\prime}$ & 0.000627666 & $* *$ & 0.000298592 & 4.41878 \\
\hline$\left[\ln S P\left(A G_{6}\right)\right]^{2} \times D d 1^{\prime}$ & 0.00429081 & $* * *$ & 0.000355042 & 146.05448 \\
\hline$[\ln A G \text { Area }]^{2} \times D d 1^{\prime}$ & -0.000603765 & $* * *$ & 0.0000931 & 42.04718 \\
\hline$D_{1} \times[\ln A G \text { Area }]^{2} \times D d 1^{\prime}$ & -0.000332436 & $* * *$ & 0.0000755 & 19.40138 \\
\hline$D_{2} \times[\ln \text { AGArea }]^{2} \times D d 1^{\prime}$ & -0.000277935 & $* * *$ & 0.000067 & 17.18268 \\
\hline$D_{3} x[\ln A G$ Area $] 2 x D d 1^{\prime}$ & -0.0000922 & & 0.00008 & 1.32646 \\
\hline$D_{4} \times[\ln A G \text { Area }]^{2} \times D d 1^{\prime}$ & 0.000485701 & $* * *$ & 0.0000813 & 35.71807 \\
\hline$D_{5} \times[\ln A G A r e a]^{2} \times D d 1^{\prime}$ & 0.000218882 & $* * *$ & 0.0000765 & 8.19019 \\
\hline $\mathrm{R}^{2}$ & 0.89 & & & \\
\hline AIC & $12,083.60$ & & & \\
\hline SC & $12,691.2$ & & & \\
\hline LIK & -5976.8 & & & \\
\hline
\end{tabular}

Note $^{*}$ : Numbers with ${ }^{*}{ }^{* *}$, and ${ }^{* * *}$ indicate that the estimated coefficients are significantly different from zero at $10 \%, 5 \%$, and $1 \%$ significance levels, respectively.

As with the significance level of estimated coefficients for NIMBY or YIMBY facilities, the relevant attributes of this study located in different development zones are significantly different from zero at different significance levels, with the exception of six impact boundaries of housing with an adjacent NIMBY or YIMBY facility or the size of cropland-type open space in a business metropolitan living zone. This result reveals that it is essential to take into account NIMBY or YIMBY facilities by evaluating either urban open space or cropland.

\subsubsection{Marginal Benefit of Surrounding Total Area for Housing Units in Each Zone}

Since the boundary impacts of NIMBY or YIMBY facilities on housing prices have been determined by local polynomial regression, it is meaningful to estimate the marginal and total benefit for the area surrounding a housing unit for urban open space or cropland in any development zone. For instance, the marginal benefit for urban open space in a business metropolitan living zone (BMLZ) without accounting for NIMBY or YIMBY facilities is computed as in (8):

$$
\frac{\text { dprice }}{\text { dOSarea }}=\frac{2 \alpha_{22}}{(1-\rho)} \ln \overline{\text { OSarea }_{D d 1}} \times \frac{\overline{\text { price }_{D d 1}}}{\overline{\text { OSarea }_{D d 1}}}
$$


where $\overline{\text { price }_{D d 1}}$ is the average housing price measured in TWD and $\overline{\text { SSarea }_{D d 1}}$ is the average area of urban open space within a 1350-m radius of a transacted housing unit in a BLMZ. Marginal benefit for urban open space with and without all other NIMBY and YIMBY facilities in a BMLZ can be computed consequently. A similar approach is used for cropland with and without the same facilities in the other five development zones, that is, the nonbusiness metropolitan living zone (NBMLZ).

The results show that within a 1350-m radius of a specific housing unit, the housing prices will increase TWD 2.20 and TWD 3.78 for a one-square-meter increase of urban open space in a BMLZ and NBMLZ without an adjacent YIMBY or NIMBY facility. They are shown as shaded orange and blue bars with numerical circles in squares in Figure 4 . The same procedure is conducted to compute the marginal benefit within a $1350-\mathrm{m}$ radius of a specific housing unit for cropland-type open space. The marginal benefit is TWD 0.14 and the marginal damage TWD 0.28 for a one-square-meter increase in cropland in the BMLZ and NBMLZ, respectively; these are shown as green and yellow bars with numerical circles in squares in Figure 4.

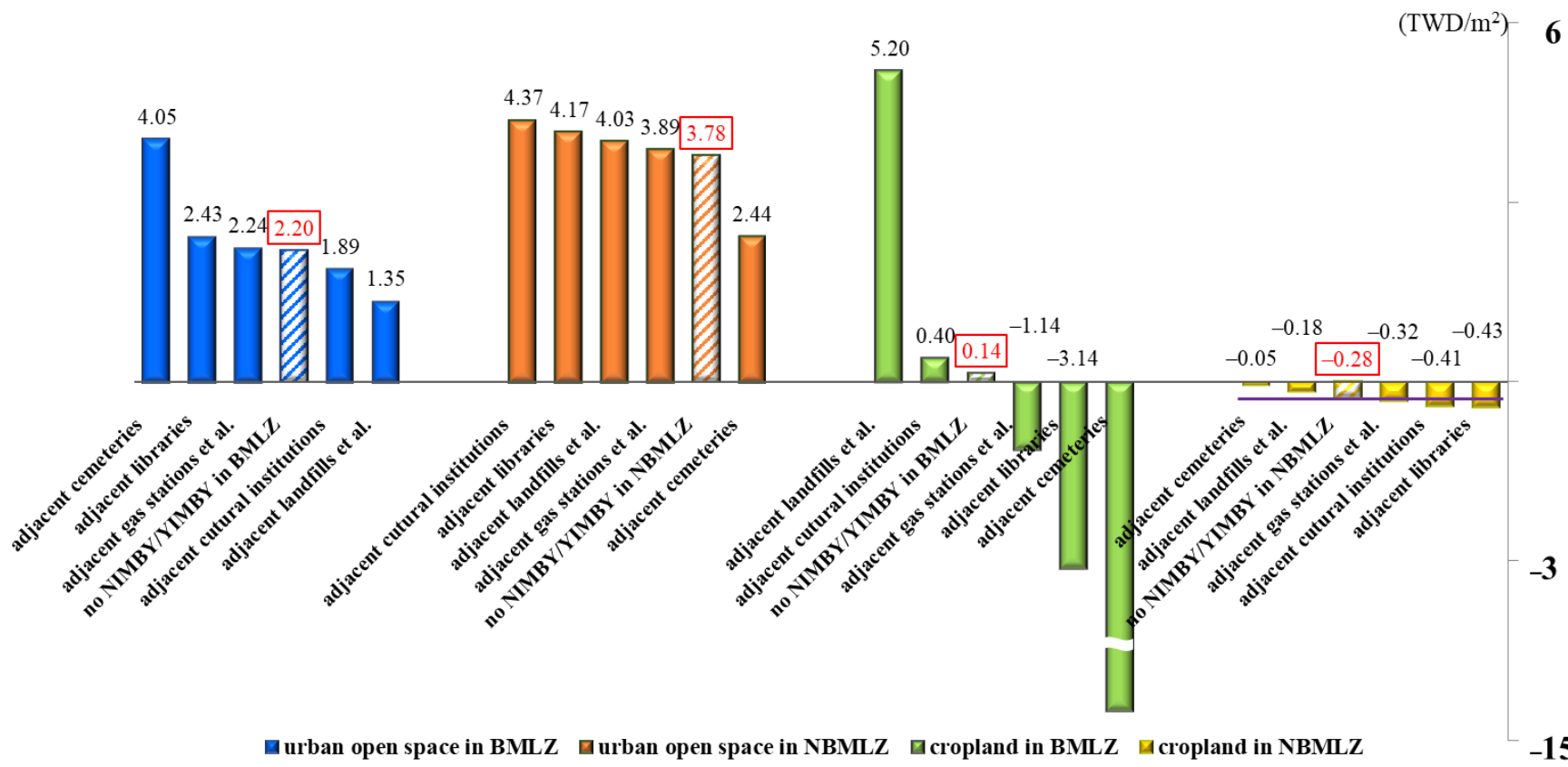

Figure 4. Marginal benefit/marginal harm for urban open space and cropland with/without. NIMBY or YIMBY facility in BMLZ or NBMLZ.

The above four magnitudes are used as references to compare the marginal benefit or marginal harm for either urban or cropland-type open space, accounting for adjacent YIMBY or NIMBY facilities in the BMLZ or NBMLZ. The urban open space and adjacent YIMBY libraries and cultural institutions generate five marginal benefits or marginal harms in the BMLZ and NBMLZ, respectively. Similarly, NIMBY facilities such as cemeteries, gas stations, circuit towers, and substations, and landfills and sewage treatment plants generate the other five different marginal benefits or marginal harms in the BMLZ and NBMLZ, respectively. The marginal benefit and marginal harm for urban open space and cropland with and without accounting for the NIMBY or YIMBY facilities in the BMLZ and NBMLZ form four groups, as shown in Figure 4.

In addition to the reference bar for each group, each group of other bars represents the marginal benefit or marginal harm for urban-type or cropland-type open spaces in the BMLZ and NBMLZ, accounting for the adjacent YIMBY or NIMBY facility. The bar located on the right-hand side of each reference bar indicates that the marginal benefit is overestimated, or the marginal harm is underestimated without accounting for the adjacent NIMBY or YIMBY facilities. Taking the group of blue-colored bars as an example, library is 
a type of adjacent YIMBY facility for urban open space in the BMLZ. All the other groups have similar explanations as above. A purple horizontal line is drawn on the top of the reference bar for each group. This makes it easy to observe the amount of underestimation or overestimation when the adjacent YIMBY or NIMBY facility is ignored in the evaluation.

It is abnormal to have a higher marginal benefit for urban open space with adjacent cemeteries. This is because Kaohsiung's government has restructured the appearance of the city to promote travel and tourism and has better utilization of land resources since the 2010 merger of old Kaohsiung City and Kaohsiung County into a municipal city. Thus, the reallocation of public cemeteries proceeded until June 2018. Among 165 public cemetery sites, 132 are prohibited from being used as burial places and are arranged as parks [51]. This makes housing purchasers expect that these lands will become large parks or even forest parks. Urban open space with adjacent cultural institutions has lower marginal benefit than space without such entities. This may arise from a higher preference for cultural institutions per se rather than adjacent facilities within an urban open space.

The results also indicate that although residents view housing surrounded by cropland as negative, the type of open space with adjacent NIMBY facilities, such as cemeteries or landfills and sewage treatment plants, will reduce the harm. That is, compared to cemeteries or landfills and sewage treatment plants adjacent to cropland, the harm caused by pure cropland is lesser. On the other hand, when cropland has YIMBY adjacent libraries or cultural institutions, this makes the harm greater than that caused by cropland only. This indicates that it is difficult to increase the benefit of libraries or cultural institutions on cropland.

\subsection{Total Benefit of Urban Open Space or Cropland with Different Adjacent NIMBY or YIMBY} Facilities in Each Zone

According to the marginal benefit or harm listed in Figure 4, the total benefit for urban open space and cropland with and without accounting for an adjacent NIMBY or YIMBY facility for the BMLZ and NBMLZ can be computed. It can be observed from Table 4 that the total benefit for the business metropolitan living zone in the BMLZ is overestimated and the total harm for the slow easy lifestyle zone in the NMBLZ is underestimated when we do not account for adjacent NIMBY or YIMBY facilities. This indicates that the allocation of NIMBY or YIMBY facilities in these two zones is inappropriate as the benefit of urban open space with either adjacent type of facility will be reduced and the harm of cropland with either adjacent type of facility will be increased. For the other four zones, that is, the NMBLZ, the total benefit is underestimated if an adjacent NIMBY or YIMBY facility is ignored within the impact radius of the transacted housing unit. The NIMBY or YIMBY facilities allocated in the NMBLZ will then increase the total benefit of the open space within $1350 \mathrm{~m}$ surrounding the transacted housing unit.

\subsection{Share of Total Benefit or Harm for Open Space to the Average Housing Price}

Computing the benefit for urban open space and cropland to the average housing price in each zone indicates how much open space is worth for each transacted housing unit. The average benefit of open space for each housing unit in a BMLZ is approximately TWD 681,000 . This represents $7.43 \%$ of the average housing price in a highly urbanized and active business zone. The average benefit is also computed for the NBMLZ, and the results are shown in Table 5. 
Table 4. Total benefit of urban open space and cropland with and without different kinds of adjacent NIMBY or YIMBY facilities in different development zones.

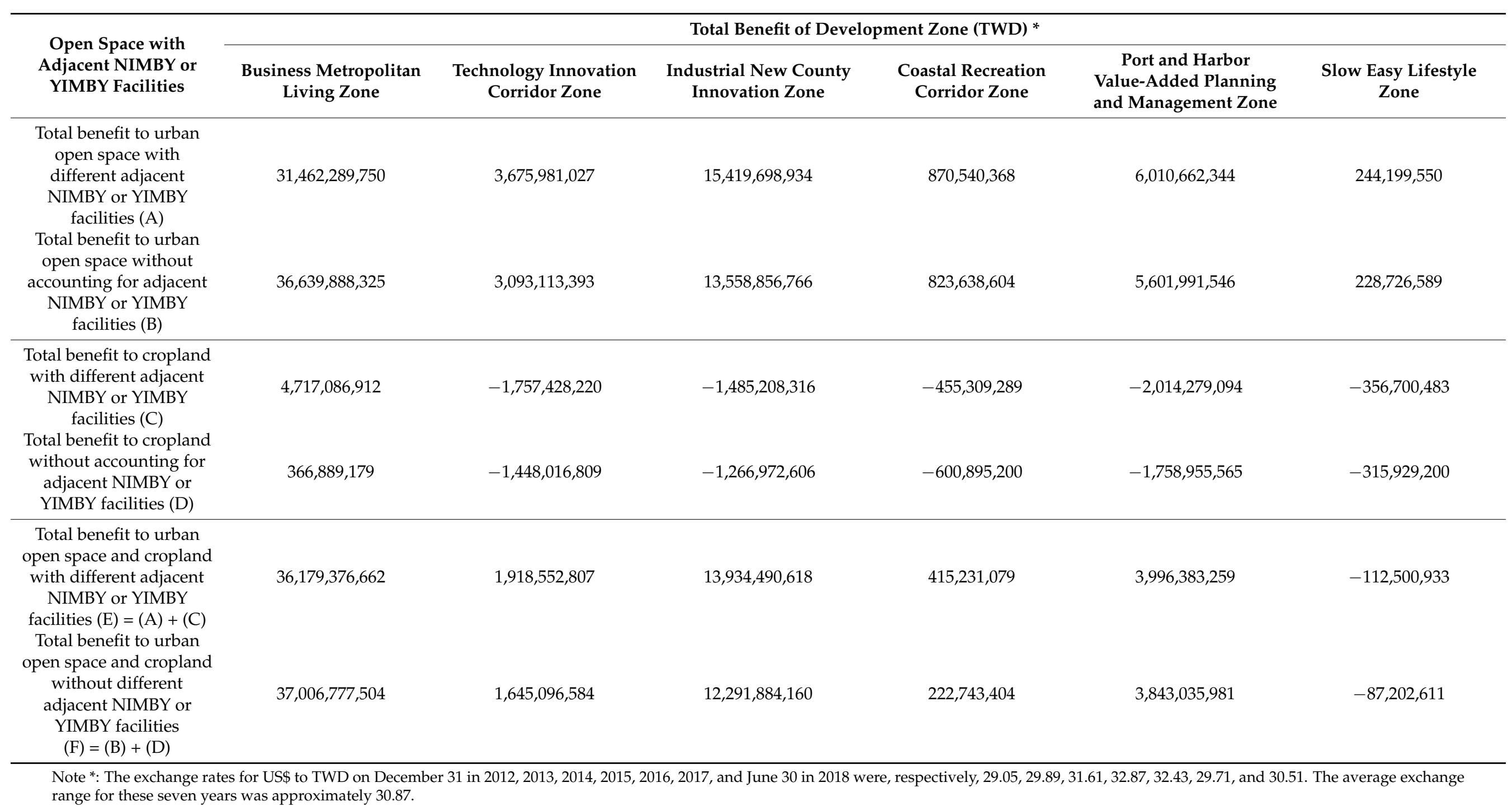


Table 5. Share of benefit or harm with adjacent NIMBY or YIMBY facilities for the average housing price in each different zone.

\begin{tabular}{|c|c|c|c|c|}
\hline Development Zone & $\begin{array}{c}\text { Number of Transacted Housing } \\
\text { Units (A) }\end{array}$ & $\begin{array}{c}\text { Average Housing Price (TWD Per } \\
\text { Housing Unit) (B) }\end{array}$ & $\begin{array}{l}\text { Total Benefit for Open Space with } \\
\text { Adjacent NIMBY or YIMBY } \\
\text { Facilities for Each Zone (TWD) (C) }\end{array}$ & $\begin{array}{l}\text { Average Benefit or Harm for Each } \\
\text { Housing Unit with Adjacent } \\
\text { NIMBY or YIMBY Facilities (TWD } \\
\text { per Housing Unit) * (D) }=\text { (C)/(A) }\end{array}$ \\
\hline Business metropolitan living zone & 53,129 & $9,160,854$ & $36,179,376,662$ & $\begin{array}{l}680,972 \\
(7.43 \%)\end{array}$ \\
\hline Technology innovation corridor zone & 5658 & $7,708,265$ & $1,918,552,807$ & $\begin{array}{l}339,087 \\
(4.40 \%)\end{array}$ \\
\hline $\begin{array}{l}\text { Industrial new county innovation } \\
\text { zone }\end{array}$ & 13,950 & $7,240,300$ & $13,934,490,618$ & $\begin{array}{c}998,888 \\
(13.80 \%)\end{array}$ \\
\hline Coastal recreation corridor zone & 2602 & $5,409,910$ & $415,231,079$ & $\begin{array}{l}159,582 \\
(2.95 \%)\end{array}$ \\
\hline $\begin{array}{l}\text { Port and harbor value-added } \\
\text { planning and management zone }\end{array}$ & 7795 & $5,482,790$ & $3,996,383,250$ & $\begin{array}{l}512,685 \\
(9.35 \%)\end{array}$ \\
\hline Slow, easy lifestyle zone & 1598 & $3,765,386$ & $-112,500,934$ & $\begin{array}{l}-70,401 \\
(1.87 \%)\end{array}$ \\
\hline
\end{tabular}

Note *: Number in parentheses is the share of benefit or harm per housing unit in each zone. 
The slow easy lifestyle zone has a negative total benefit of open space and cropland, that is, total harm of TWD 70,000 or $1.87 \%$ of the average housing price in this zone. The average benefit of urban open space and cropland to the average housing price for the other four zones is positive except for the slow easy lifestyle zone. These results indicate that the average benefit of the total area of surrounding urban open space and cropland within the impact radius with adjacent NIMBY or YIMBY facilities accounts for $2.95 \%$ to $13.80 \%$ of the average housing price. Surrounding NIMBY or YIMBY facilities indeed increase or decrease the benefit of open space.

\section{Conclusions}

This is the first study to comprehensively evaluate the benefit or harm to urban-type and cropland-type open spaces associated with different types of adjacent NIMBY or YIMBY facilities. The urbanized zone in Kaohsiung shows that without accounting for these adjacent facilities, the total benefit is overestimated for urban-type open space and underestimated for cropland-type open space. Moreover, the total benefit for areas with mixed urban-type and cropland-type open spaces will be higher if their adjacent NIMBY or YIMBY facilities are accounted for. The situation is reversed because the total croplandtype open space accounts for more than $80 \%$ in the zone. The results suggest that NIMBY or YIMBY facilities located in an area with a larger share of urban-type open space will significantly increase the positive impact of YIMBY facilities and mitigate the negative impact of NIMBY facilities. These results serve as a guideline for further arrangement of different NIMBY or YIMBY facilities in each zone with different proportions of urban-type and cropland-type open space in the city.

From the viewpoint of the individual housing unit for the case at hand, the total harm for cropland-type open space with an adjacent NIMBY or YIMBY facility is equivalent to $1.87 \%$ of the average housing price for areas with a high percentage of cropland. The total benefit for urban-type open space with adjacent NIMBY or YIMBY facilities is equivalent to $7.43 \%$ of the average housing price for highly urbanized areas. In comparison, the total benefit accounts for $2.95-13.80 \%$ of the average housing price for areas with mixed urban-type and cropland-type open space. This clearly indicates that failure to account for either type of open space with adjacent NIMBY or YIMBY facilities will result in the overestimation or underestimation of housing prices by a substantial amount, especially given high average housing prices in Taiwan.

The results from this study are not to be extended to other NIMBY or YIMBY facilities since each city and area are occupied by different NIMBY and/or YIMBY facilities. A better idea is to employ the methodology proposed in this study and to collect as many as necessary facilities before the benefit of open space or cropland is evaluated. Without appropriate evaluation and reliable benefit results, gathering complete information for the allocation or disposition of NIMBY or YIMBY facilities for any planned zone will not be possible.

Author Contributions: Conceptualization, W.-J.W. and P.-I.W.; methodology, W.-J.W.; software, W.-J.W.; validation, J.-L.L.; formal analysis, W.-J.W. and P.-I.W.; investigation, W.-J.W.; resources, P.-I.W.; data curation, W.-J.W.; writing - original draft preparation, P.-I.W.; writing-review and editing, J.-L.L.; visualization, J.-L.L.; supervision, P.-I.W.; project administration, P.-I.W.; funding acquisition, P.-I.W. All authors have read and agreed to the published version of the manuscript.

Funding: This research was funded by the Ministry of Science and Technology, Taiwan (MOST) under Grant No. MOST 106-2410-H-002-204-MY2.

Data Availability Statement: Data is not publicly available, though the data may be made available on request from the corresponding author.

Conflicts of Interest: The authors declare no conflict of interest. 


\section{References}

1. Bomans, K.; Dewaelheyns, V.; Gulinck, H. Pasture for horses: An underestimated land use class in an urbanized and multifunctional area. Int. J. Sustain. Dev. Plan. 2011, 6, 195-211. [CrossRef]

2. Department of Economic and Social Affairs of the United Nations. The Sustainable Development Goals Report 2018, United Nations, New York. Available online: https://unstats.un.org/sdgs/report/2018/goal-11/ (accessed on 20 December 2020).

3. Luttik, J. The value of trees, water and open space as reflected by house prices in the Netherlands. Landsc. Urban Plan. 2000, 48, 161-167. [CrossRef]

4. Melichar, J.; Kaprová, K. Revealing preferences of Prague's homebuyers toward greenery amenities: The empirical evidence of distance-size effect. Landsc. Urban Plan. 2013, 109, 56-66. [CrossRef]

5. WHO Regional Office for Europe. Urban Green Spaces and Health, Copenhagen: WHO Regional Office for Europe. Available online: http:/ / www.euro.who.int/_data/assets/pdf_file/0005/321971/Urban-green-spaces-and-health-review-evidence.pdf? ua $=1$ (accessed on 22 November 2020).

6. Foster, S.; Giles-Corti, B.; Knuiman, M. Does fear of crime discourage walkers? A social-ecological exploration of fear as a deterrent to walking. Environ. Behav. 2014, 46, 698-717. [CrossRef]

7. Geoghegan, J. The value of open spaces in residential land use. Land Use Policy 2002, 19, 91-98. [CrossRef]

8. Kuminoff, N.V. Using a bundled amenity model to estimate the value of cropland open space and determine an optimal buffer zone. J. Agric. Resour. Econ. 2009, 43, 68-90.

9. Rogus, S.; Dimitri, C. Agriculture in urban and peri-urban areas in the United States: Highlights from the census of agriculture. Renew. Agric. Food Syst. 2015, 30, 64-78. [CrossRef]

10. Tsai, M.-K.; Wu, P.-I.; Liou, J.-L. Spatial hedonic quantile Durbin model for benefit evaluation of diversified open spaces in urban planning division in Taoyuan City. J. City Plan. 2019, 46, 297-341.

11. Jones, M.; Reed, R.G. Open space amenities and residential land use: An Australian perspective. Land Use Policy 2018, 75, 1-10. [CrossRef]

12. Brown, G.; Glanz, H. Identifying potential NIMBY and YIMBY effects in general land use planning and zoning. Appl. Geogr. 2018, 99, 1-11. [CrossRef]

13. Pauleit, S.; Ambrose-Oji, B.; Andersson, E.; Anton, B.; Buijs, A.; Haase, D.; Elands, B.; Hansen, R.; Kowarik, I.; Kronenberg, J.; et al. Advancing urban green infrastructure in Europe: Outcomes and reflections from the GREEN SURGE project. Urban For. Urban Green. 2019, 40, 4-16. [CrossRef]

14. Maxwell, N.K. Libraries?-Yes, in My Backyard! J. Access Ser. 2008, 5, 391-396. [CrossRef]

15. Hite, D.; Chern, W.; Hitzhusen, F.; Randall, A. Property-value impacts of an environmental disamenity: The case of landfills. J. Real Estate Financ. 2001, 22, 185-202. [CrossRef]

16. Clark, D.E.; Michelbrink, L.; Allison, T.; Metz, W.C. Nuclear power plants and residential housing prices. Growth Chang. 1997, 28, 496-519. [CrossRef]

17. Burger, J.; Gochfeld, M. Initiating events, functional remediation, and assessment of risk to ecological resources. Ecol. Indic. 2016, 71, 32-40. [CrossRef]

18. Al-Akl, N.M.; Karaan, E.N.; Al-Zein, M.S.; Assaad, S. The landscape of urban cemeteries in Beirut: Perceptions and preferences. Urban For. Urban Green. 2018, 33, 66-74. [CrossRef]

19. Connolly, C.; Livy, M.R.; Qiu, Y.; Klaiber, H.A. Capitalization of interconnected active transportation infrastructure. Landsc. Urban Plan. 2019, 182, 67-78. [CrossRef]

20. Jucu, I.S.; Voiculescu, S. Abandoned places and urban marginalized sites in Lugoj Municipality, three decades after Romania's State-Socialist collapse. Sustainability 2020, 12, 7627. [CrossRef]

21. Jucu, I.S. Recent issues of spatial restructuring in Romanian medium-sized towns: Spatial conversion and local urban regeneration. Int. Multidiscip. Sci. GeoConf. SGEM Conf. Proc. 2016, 3, 493-500. [CrossRef]

22. Construction and Planning Agency, Ministry of the Interior. National Spatial Planning. Taipei: Construction and Planning Agency, Ministry of the Interior. Available online: https:/ / www.cpami.gov.tw/filesys/file/rp6/rp1070430_3.pdf (accessed on 15 December 2020).

23. Petrescu-Mag, R.M.; Petrescu, D.C.; Reti, K.-O. My land is my food: Exploring social function of large land deals using food security-Land deals relation in five eastern European countries. Land Use Policy 2019, 82, 729-741. [CrossRef]

24. LeSage, J.; Pace, R.K. Introduction to Spatial Econometrics; Chapman and Hall/CRC: Boca Raton, FL, USA, 2009.

25. Anselin, L.; Exploring Spatial Data with GeoDaTM: A Workbook. Santa Barbara, California: Center for Spatially Integrated Social Science. Available online: http:/ / www.csiss.org/clearinghouse/GeoDa/geodaworkbook.pdf (accessed on 5 January 2021).

26. Tanaka, S.; Zabel, J. Valuing nuclear energy risk: Evidence from the impact of the Fukushima crisis on U.S. house prices. J. Environ. Econ. Manag. 2018, 88, 411-426. [CrossRef]

27. Linden, L.; Rockoff, J.E. Estimates of the impact of crime risk on property values from Megan's laws. Am. Econ. Rev. 2008, 98, 1103-1127. [CrossRef]

28. McConnell, V.; Walls, M. The Value of Open Space: Evidence from Studies of Nonmarket Benefits, Working Paper. Resources for the Future, Washington, D.C. Available online: http://www.rff.org/files/sharepoint/WorkImages/Download/RFF-REPORTOpen\%20Spaces.pdf (accessed on 10 November 2020). 
29. Bocchiola, D.; Brunetti, L.; Soncini, A.; Polinelli, F.; Gianinetto, M. Impact of climate change on agricultural productivity and food security in the Himalayas: A case study in Nepal. Agric. Syst. 2019, 171, 113-125. [CrossRef]

30. Bernués, A.; Rodríguez-Ortega, T.; Alfnes, F.; Clemetsen, M.; Eik, L.O. Quantifying the multifunctionality of Fjord and Mountain agriculture by means of sociocultural and economic valuation of ecosystem services. Land Use Policy 2015, 48, 170-178. [CrossRef]

31. Goldstein, B.; Hauschild, M.; Fernandez, J.; Birkved, M. Testing the environmental performance of urban agriculture as a food supply in northern climates. J. Clean. Prod. 2016, 135, 984-994. [CrossRef]

32. Renting, H.; Rossing, W.A.H.; Groot, J.C.J.; van der Ploeg, J.D.; Laurent, C.; Perraud, D.; Stobbelaar, D.J.; van Ittersum, M.K. Exploring multifunctional agriculture: A review of conceptual approaches and prospects for an integrative transitional framework. J. Environ. Manag. 2009, 90, S112-S123. [CrossRef]

33. Swensen, G.; Nordh, H.; Brendalsmo, J. A green space between life and death-A case study of activities in Gamlebyen cemetery in Oslo, Norway, Norsk Geografisk Tidsskrift-Norwegian. J. Geogr. 2016, 70, 41-53.

34. Haase, D.; Jänicke, C.; Wellmann, T. Front and back yard green analysis with subpixel vegetation fractions from earth observation data in a city. Landsc. Urban Plan. 2019, 182, 44-54. [CrossRef]

35. Construction and Planning Agency, Ministry of the Interior. The Statistical Yearbook of Construction and Planning Agency Ministry of Interior. Taipei: Construction and Planning Agency, Ministry of the Interior. Available online: https://www.cpami. gov.tw / filesys / file/chinese/new1/n108030.pdf (accessed on 10 November 2020).

36. Construction and Planning Agency, Ministry of the Interior. National and Six Municipality Housing Price Index for 2016 Base Year. Taipei: Construction and Planning Agency, Ministry of the Interior. Available online: https://www.cpami.gov.tw/publicinformation/statistics/34110-106.html (accessed on 15 November 2020).

37. Rosen, S. Hedonic prices and implicit markets: Product differentiation in pure competition. J. Polit. Econ. 1974, 82, 34-55. [CrossRef]

38. Anselin, L. Spatial Econometrics: Methods and Models; Kluwer Academic Publishers: Dordrecht, The Netherlands, 1988.

39. Herath, S.; Choumert, J.; Maier, G. The value of the greenbelt in Vienna: A spatial hedonic analysis. Ann. Reg. Sci. 2015, 54, 349-374. [CrossRef]

40. Wu, P.-I.; Chen, Y.; Qiu, K.-Z. Effect of wetlands on residential property values and evaluation of environmental damage with development of wetlands: GIS-based of spatial hedonic price method. Agric. Econ. 2015, 55, 37-82.

41. Fernandez, M.A.; Bucaram, S. The changing face of environmental amenities: Heterogeneity across housing submarkets and time. Land Use Policy 2019, 83, 449-460. [CrossRef]

42. Lai, M.-C.; Wu, P.-I.; Liou, J.-L.; Chen, Y.; Chen, H. The impact of promoting renewable energy in Taiwan: How much hail is added to snow in farmland prices? J. Clean. Prod. 2019, 241, 118519. [CrossRef]

43. Xue, C.; Ju, Y.; Li, S.; Zhou, Q. Research on the sustainable development of urban housing price based on transport accessibility: A case study of Xi'an, China. Sustainability 2020, 12, 1497. [CrossRef]

44. Bai, Y.; Song, J.; Wu, S.; Wang, W.; Lo, J.T.Y.; Lo, S.M. Comparing the impacts of location attributes on residents' preferences and residential values in compact cities: A case study of Hong Kong. Sustainability 2020, 12, 4867. [CrossRef]

45. Fan, J. Design-adaptive nonparametric regression. J. Am. Stat. Assoc. 1992, 87, 998-1004. [CrossRef]

46. Fan, J.; Gijbels, I.; Hu, T.C.; Huang, L.S. A study of variable bandwidth selection for local polynomial regression. Stat. Sin. 1996, 6, 113-127.

47. Ministry of the Interior. Web Service of Actual Real Transaction of Real Estates. Taipei: Ministry of the Interior. Available online: http:/ /lvr.land.moi.gov.tw / homePage.action (accessed on 10 November 2020).

48. Sirmans, G.S.; MacDonald, L.; Macpherson, D.A.; Zietz, E. The value of housing characteristics: A meta-analysis. J. Real Estate Financ. 2006, 33, 215-240. [CrossRef]

49. Taiwan Geospatial One-Stop Portal. National House Number Address Location Service.Ministry of Interior, Taiwan. Available online: https: / / www.tgos.tw/tgos/Web/Address/TGOS_Address.aspx (accessed on 25 November 2020).

50. Cropper, M.L.; Deck, L.B.; McConnell, K.E. On the choice of functional form for hedonic price functions. Rev. Econ. Stat. 1988, 70, 668-675. [CrossRef]

51. Urban and Rural Development Branch, Construction and Planning Agency, Ministry of the Interior. Kaohsiung City Planning Land Use Zoning Map (TWD97) Latitude and Longitude; Urban and Rural Development Branch, Construction and Planning Agency, Ministry of the Interior: Kaohsiung, Taiwan, 2018. 